\title{
Social networks as tools for acquiring competences at university: QR codes through Facebook
}

\author{
Pedro Román Graván' and Ángela Martín Gutiérrez ${ }^{\mathbf{2}}$ \\ 1. University of Seville, Spain | proman@us.es \\ 2. University of Seville, Spain | amartin9@us.es
}

Submitted in: November 2013

Accepted in: February 2014 Published in: May 2014

\section{Recommended citation}

Román, P. \& Martín, A. (2014). Social networks as tools for acquiring competences at university: QR codes through Facebook. RUSC. Universities and Knowledge Society Journal, 11(2). pp. 26-40. doi http://dx.doi.org/10.7238/rusc.v1112.2050

\begin{abstract}
Immersed in an academic system where the curriculum teaches students specific skills in order to develop a future profession, social networks, as specialised environments primarily in informal education settings, prepare them in attaining innovative and emerging competences that are not found in the curriculum. Here we present the results of an innovative study funded by the Institute of Education Sciences at the University of Seville (US), Spain, and the Faculty of Economic and Social Sciences at the University of Carabobo (UC), Venezuela, encompassing a collaborative experience of best practices. A sample of 175 students was used in the study, of whom 55 were obtaining a degree in Business Administration at UC, and 120 were studying in the Faculty of Education Sciences at US. Among the most significant findings, we affirm that Facebook, as a learning environment for studying and sharing Quick Response (QR) codes, is a tool that the student defines as close, reliable, easy to use, and has many advantages over other settings, as it becomes a place where people from different locations meet and share common educational experiences. Furthermore, this study emphasises that using Facebook allows students to acquire and/or develop instrumental, interpersonal, and systemic competences.
\end{abstract}

\section{Keywords}

social networks, competences, skills, university, QR codes, collaborative work

\section{Las redes sociales como herramientas para la adquisición de competencias en la universidad:}

\section{los códigos QR a través de Facebook}

\section{Resumen}

Sumidos en un sistema académico en donde los planes de estudio capacitan a los estudiantes en determinadas competencias para desarrollar una futura profesión, las redes sociales, como entornos especializados fundamentalmente en educación no formal, los preparan para adquirir las emergentes e innovadoras competencias que no se contemplan en el currículo. En este artículo se exponen los resultados de un proyecto de innovación financiado por el Instituto de Ciencias de la Educación de la Universidad de Sevilla y la Facultad de Ciencias Económicas y Sociales de la Universidad de Carabo- 
bo (Venezuela), así como se da cuenta de una experiencia colaborativa de buenas prácticas. Se ha trabajado con una muestra total de 175 estudiantes, de los cuales 55 pertenecen a la titulación de Administración Comercial (Universidad de Carabobo, Venezuela), y el resto a la Facultad de Ciencias de la Educación (Universidad de Sevilla, España). Entre las conclusiones más significativas, se afirma que la red social Facebook, como entorno de aprendizaje para conocer y compartir los códigos de respuesta rápida o códigos QR, es una herramienta que el alumnado define como cercana, fiable, de fácil manejo y que posee muchas ventajas con respecto a otros entornos, ya que se convierte en un espacio donde se conocen personas de distintos lugares y que comparten experiencias educativas comunes. Además, se hace hincapié en que, al utilizar Facebook, pueden adquirirse y/o desarrollarse competencias instrumentales, interpersonales y sistémicas.

\section{Palabras clave}

redes sociales, competencias, universidad, códigos $Q R$, trabajo colaborativo 


\section{Introduction and the status of the question}

The university is one of the oldest and most enduring social institutions of all time, and in one way or another, has always been able to adapt to a changing world (Bombillar, 2010). It is within this context of constant change characterised by increasing globalisation - wherein the use of information and communication technologies (ICT), the mobility of knowledge and the development of new social attitudes, among others, are becoming more and more important - that the European Higher Education Area (EHEA) is located. According to Marín and Romero (2009), it situates the university at a time of profound change, especially with respect to methodology (De Miguel, 2005).

From this perspective, there is an urgent need for initial and lifelong training to prepare teachers for their new role and adaptation to a dynamic and changing market (Moreno, 2011; Zambrana \& Manzano, 2004).

Social networks have now become real learning spaces for students, and there is talk of the learning possibilities they hold, with the idea that they be used in formal, non-formal and/or entertainment settings. Ivala and Gachago (2012) believe that Web 2.0 tools such as Facebook and blogs can be effective in improving levels of student engagement in learning, i.e. they can have a positive impact on their levels of participation and involvement in learning, and help university students acquire and improve their competences (Manca \& Ranierit, 2013).

Concerning competences, it is worth remembering that these have been present in our lives for centuries (Cano, 2007). One of the first taxonomies was the Tuning project (2007) proposal, which classified them as general (generic) and specific (degree-related), while the EHEA classification (Martínez López, 2008) proposed a different classification: instrumental, interpersonal and systemic competences.

From this point of view, the objective of this study was to determine what competences participating university students' obtained after learning about QR codes through Facebook.

There are numerous experiences of using QR codes in education. With regard to higher education, we would highlight those found in the libraries of Harvard (2012), Stanford (2012), Seville (2012) and Oviedo (2012). There, they state that these codes can be used in university settings as collections of resources for students, through leaflets with different symbols linked to online resources that the student must read for a subject, topic or chapter. In laboratory environments, the codes can connect the laboratory equipment with detailed instructions on how to use it.

In other studies (Geyer, 2010; Marquis, 2012; Watson, 2013), QR codes have been used in universities as a way to integrate audiovisual media in reports, for example, to add videos or computerised group presentations, or to link them to simple surveys created with Google Drive or Doodle.

We could view them as gateways to bring external resources into the classroom or to help students acquire information beyond the walls of the university; this is the starting point for thinking about how these small squares might enhance any classroom lesson (Allueva, 2013).

In non-university education, experiences similar to those described above have also been undertaken; in this case, QR codes have been used mainly from a curricular perspective: to learn music, environmental studies, social sciences, language, and even foreign languages like English (Domenech, 2011; Hernández Ortega, 2012; Gamboa Jiménez, 2012; Gálvez, 2012).

As for the uses of Facebook in higher education, different authors have used it as a support or tool for storing information or for making their classes more up to date (Gómez \& López, 2010; Morelli, 2011; Reig, 2011; Piñol Bastidas, 2012; Ivala \& Gachago, 2012; Manca, 2013; Konstantinou, 2013). Generally, it has been used as a repository 
for Web resources, where students are able to share their opinions, which they themselves appreciate. It may also contain anything from links to materials like blogs or websites, to videos and pictures, all of which develop and enhance collaborative learning.

\section{Method}

A cross-sectional descriptive study was conducted as part of a broader innovative, good practices experience with university students from Spain and Venezuela obtaining various degrees (Román Graván, 2012; Román, Díaz, Puig, \& Martín, 2012). During the 2011/12 and 2012/13 academic years, students from the Faculty of Economic and Social Sciences (FACES, to use the Spanish acronym) at the University of Carabobo (UC), Venezuela, and the Faculty of Education Sciences (FCCE, to use the Spanish acronym) at the University of Seville (US), Spain, participated in the study. The objectives were as follows:

a) To design and produce a virtual repository on Facebook of QR codes (Figure 1).

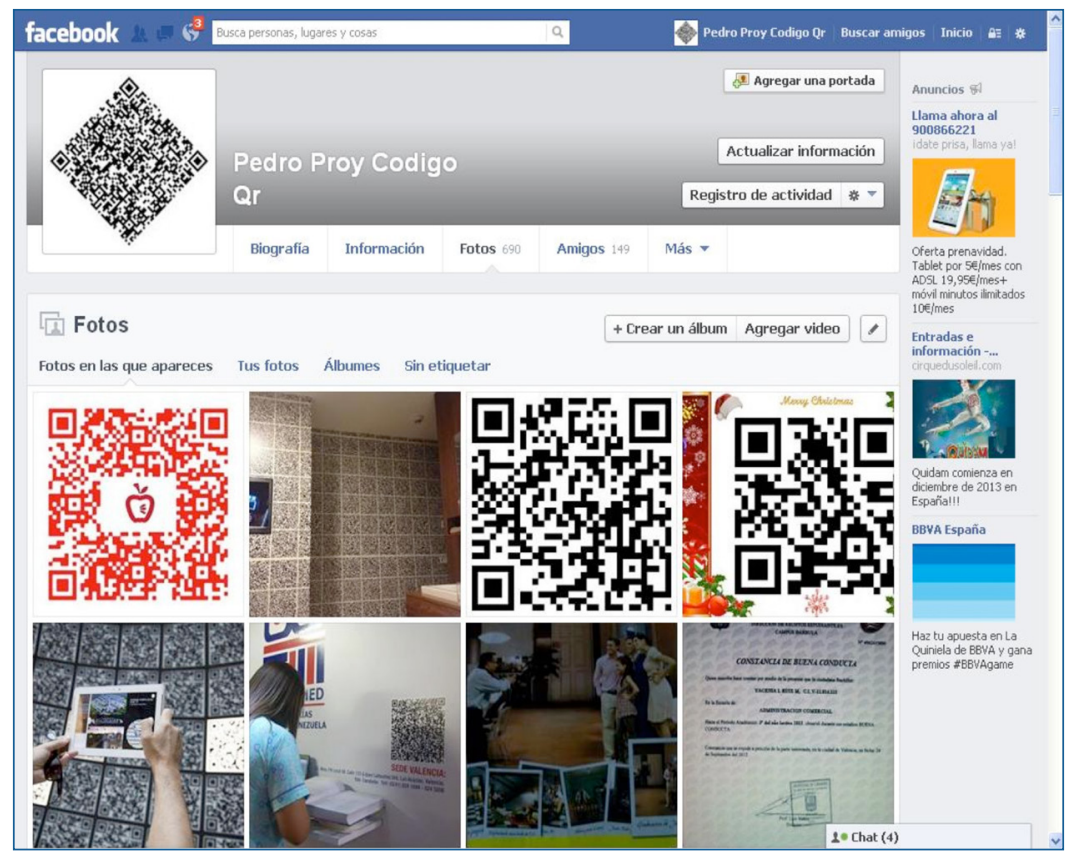

Figure 1. Virtual repository on Facebook of QR codes.

b) To collect best practices for using these codes in general education and in specific disciplines, in both university and non-university settings, to serve as an example for the whole academic community (see Figure 2). 


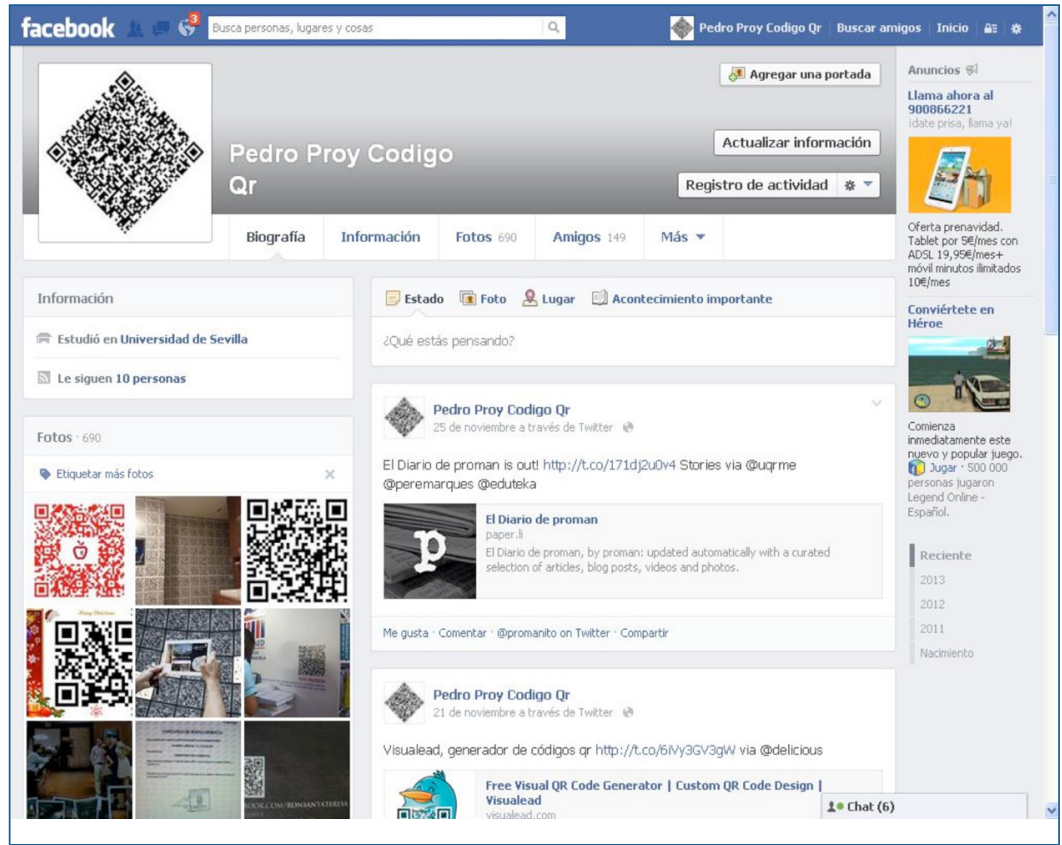

Figure 2. Virtual repository on Facebook of QR code best practices.

c) To design and develop a website that serves as a portal for access to the various parts of the project: social network where images are hosted, social bookmarking on QR codes, Tweets on Twitter about these codes, and a satisfaction questionnaire after participating in the project.

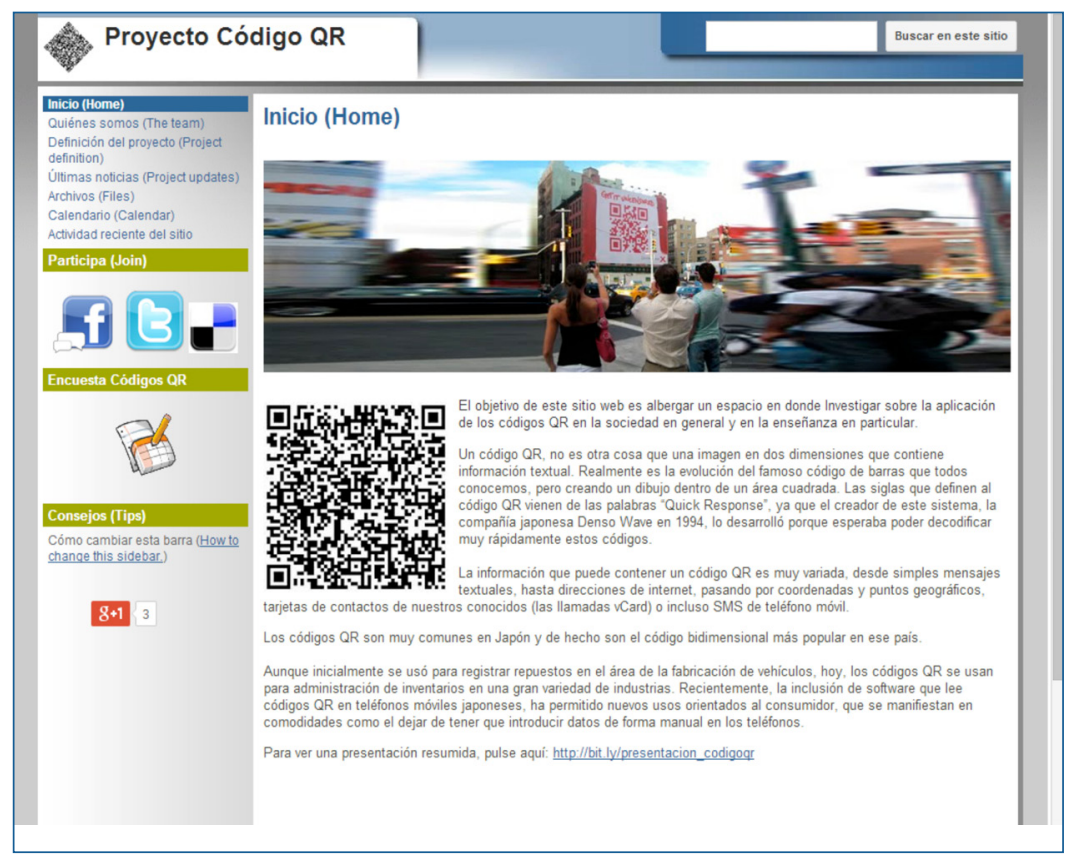

Figure 3. Access portal to the project (http://t.co/31oB8W4q). 
d) To design, implement and analyse data from a questionnaire (http://bit.ly/experiencia-facebook-qr) that evaluates the perceptions of using such codes in teaching and social networks, the development of generic competences and the level of satisfaction of those who participated in the project.

\subsection{Participants}

The sample comprised 175 students: 55 in their fourth year of the degree in Business Administration, who were enrolled in the Marketing course offered in FACES at UC, aged 19 to 60 years, and 120 students from FCCE at US obtaining either of the two degrees currently awarded (in Primary Education and in Teaching), aged 18 to 61 years (see Table 1.)

Table 1. Distribution of participants by degree, course, university and country.

\begin{tabular}{|c|c|l|c|c|c|}
\hline Group & No & \multicolumn{1}{|c|}{ Degree } & \multicolumn{1}{|c|}{ Course } & University & Country \\
\hline $\mathbf{1}$ & 49 & $\begin{array}{l}\text { Degree in Primary Education } \\
\text { (group 6), FCCE }\end{array}$ & ICT applied to education & Seville & Spain \\
\hline $\mathbf{2}$ & 41 & $\begin{array}{l}\text { Degree in Primary Education } \\
\text { (group 10), FCCE }\end{array}$ & ICT applied to education & Seville & Spain \\
\hline $\mathbf{3}$ & 30 & $\begin{array}{l}\text { Degree in Teaching (group 4), } \\
\text { FCCE }\end{array}$ & Education technology & Seville & Spain \\
\hline $\mathbf{4}$ & 33 & $\begin{array}{l}\text { Degree in Business } \\
\text { Administration (Section 31 - } \\
\text { morning session), FACES }\end{array}$ & Marketing I & Carabobo & Venezuela \\
\hline $\mathbf{5}$ & 22 & $\begin{array}{l}\text { Degree in Business } \\
\text { Administration (Section 82 - } \\
\text { evening session), FACES }\end{array}$ & Marketing I & Carabobo & Venezuela \\
\hline
\end{tabular}

(Source: Own research).

This type of sample was intentionally non-probabilistic due to the project managers' ease of access to students from both universities. We are also conscious of the fact that this work aims to be a specific case, an enclosed study that is well defined. While it may not be generalizable, we believe that it is significant for understanding the phenomena analysed, and reflective of such innovative methodologies.

\subsection{Tools}

To measure the perceptions that students had of QR codes collected via Facebook, a semantic differential attitude scale was used (Osgood, Suci, \& Tannenbaum, 1976), an instrument that has also been used in other research to analyse students' attitudes toward various technological means (Cabrero, Alba Lopez-Arenas, \& Pérez de los Ríos, 1991; Llorente Cejudo, 2008).

A second part was added to this tool, the purpose of which was to investigate issues related to participation in the study and how universities deal with these kinds of innovative work practices.

Altogether, the tool contained forty-four questions divided into two main categories: issues related to perceptions of QR codes and items regarding the students' and their universities' participation in such training 
strategies. The full questionnaire, called PERCEQR: percepciones de los códigos QR en la enseñanza (perceptions of QR codes in education), can be found at http://bit.ly/experiencia-facebook-qr.

The consistency data provided by Cronbach's alpha coefficient (Ruiz, 1998), which were obtained for the dimensions of the questionnaire (perceptions of QR codes, levels of interaction during the experience, teaching strategies, roles of teachers, use of social networks in teaching, and universities' technological adaptation) were considered quite high, given that their values ranged between 0.8 and 0.9 points. Taking the average value of 0.8875, we could assert that the tool had a reliability level of 88.75\% (Román, 2012).

Throughout this article, the results of the open items for the second set of questions will be analysed; specifically those that refer to the skill level and degree of participation and satisfaction with the experience:

40) What was your level of interaction in using this technological strategy for the course?

41) Do you consider that using social networks as a way to publicise QR codes represents an educational and motivational strategy for understanding the content of a subject?

42) What do you think the role of the teacher should be in response to the use of this type of technological media in the teaching-learning process?

43) Do you think it is important to extend the use of social networks and the methodology applied in this experiment to the whole context of the subject and not just to a specific topic?

44) Do you find that the university in general, specifically your faculty/school/institute, is technologically and methodologically prepared to use educational materials in the teaching-learning process of the course, and to use social networks in it?

\subsection{Method}

In an initial session, students were taught about QR codes - what they are and what their features and origins are. They learnt how to design them and generate them from websites. They were taught how QR code readers are installed on mobile phones and tablets with different operating systems, as well as on web browsers. They were shown different ways of using QR codes in general and specifically in teaching. They were told how to prepare and present examples of best practices. This information was also accessible through the social network and from the previously mentioned website created for the experience.

Following the theoretical explanation, students put into practice everything they learnt and completed exercises connected with these symbols. They also designed collaborative activities, contributing ideas on best practices related to the design and use of QR codes in education in general.

At the same time, they uploaded the different QR codes that they had found onto Facebook. In some cases, they took photos of them with their mobile phones, whether they were in magazines, newspapers, or on advertising boards. In other cases they uploaded them from the websites where they had found them. In this activity, students from both countries always interacted.

After the experience, the questionnaires were administered to gather information and analyse the data contained in them.

RUSC Vol. 11 No 2 Special Issue | Universitat Oberta de Catalunya and University of New England | Barcelona, May 2014

@ Pedro Román and Ángela Martín | @ by FUOC, 2014 | Social networks as tools for acquiring competences at university: QR codes through Facebook 


\subsection{Analysing the results}

The scientific software package SPSS v.18 was used for the descriptive analysis of their perceptions, and Atlas.ti v.7.0 was used for the analysis of open items, which helped to categorise the following dimensions studied in this article: levels of interaction during the experience, teaching strategies, teachers' role, use of social networks in education, and technological adaptation of universities.

\section{Results}

\section{Perceptions of QR codes}

Regarding the perceptions that students had of QR codes, the scores given to the pairs of proposed adjectives suggested that codes made the work easier; were effective, useful, positive, recommendable, beneficial and fun;

Figure 4. Perceptions that students have of QR codes (\% in blue).

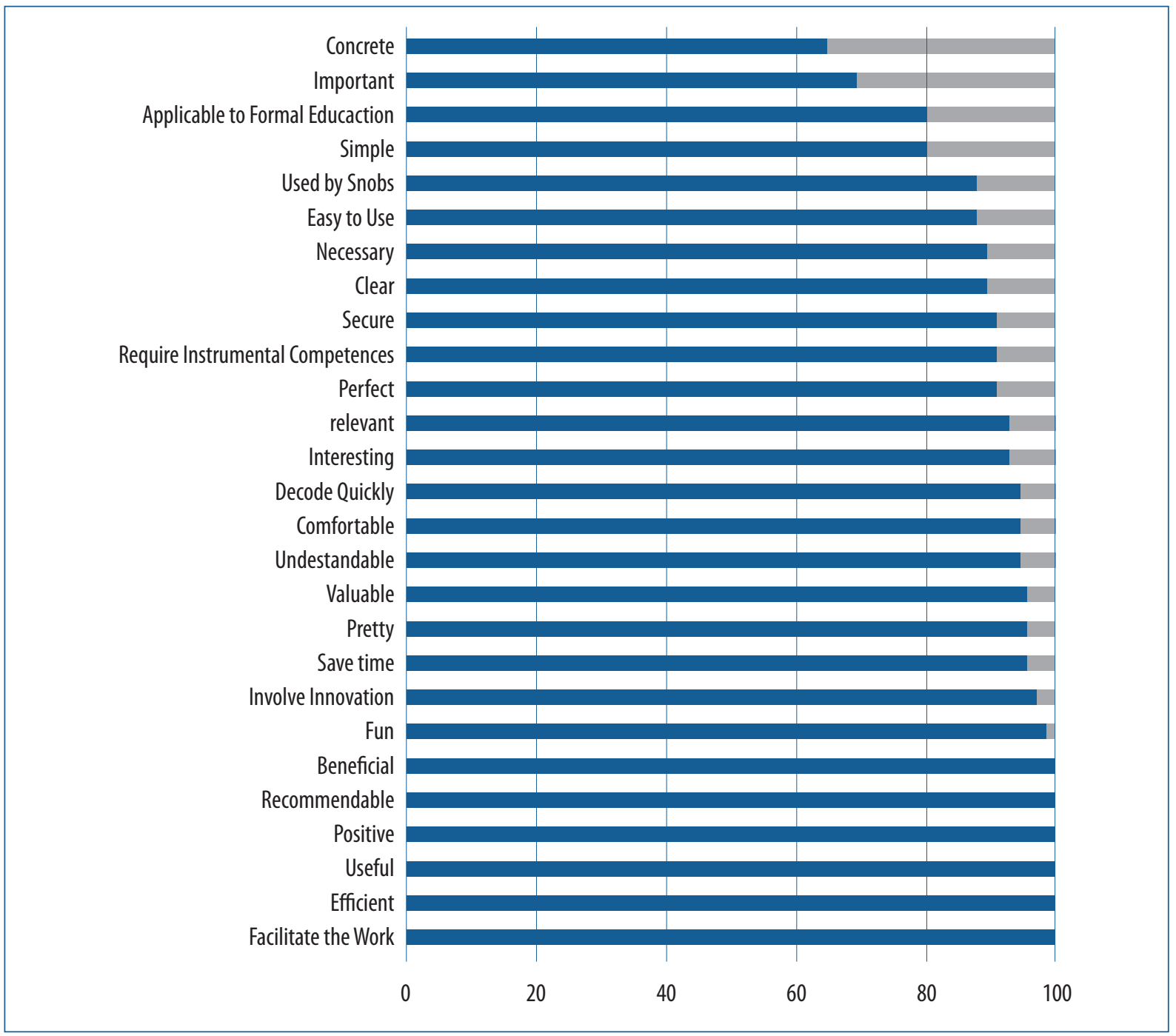


involved innovation; saved a lot of time; were pretty, valuable, entertaining and comfortable; decoded quickly; were interesting, relevant and ideal; required instrumental competences; and were secure, clear, necessary, easy to use, used by intellectuals, simple, applicable to formal education, important and concrete (see Figure 4).

With regard to the analysis of university competences that were employed using QR codes through Facebook, the university students developed the competences referred to below.

\section{Development of instrumental competences}

According to Martínez López (2008), instrumental competences include the capacity for analysis and synthesis, the ability to organise and plan, basic general knowledge, deeper understanding of the profession, oral and written communication in the language, the knowledge of one or more foreign languages, basic computer skills, computer skills related to the field of study, information management skills (ability to retrieve and analyse information from various sources), problem-solving and decision-making.

From the students' contributions, it appears that the instrumental competences that they developed the most in this experience were the ability to analyse and synthesise, and the ability to organise and plan. Below, some of the most representative opinions have been highlighted.

- Capacity for analysis and synthesis: "...trying to take enough time so as not to repeat the same thing our peers have already done [...] as long as it takes..." (Interview 8); "...clearly indicate what the QR codes are [...] as there are several types of two-dimensional codes..." (Interview 12); "...there was competitiveness because you could not repeat the pictures" (Interview 25); "...t became something interesting and competitive [...] and it really was original and different from what the others had" (Interview 51).

- Ability to organise and plan: "...there should be control over or a limit to the number of QR codes that groups can collect [...]. For the other groups, the search becomes a bit more difficult" (Interview 11).

\section{Development of interpersonal competences}

According to Martínez López (2008), interpersonal competences refer to teamwork, work in an interdisciplinary team, the ability to work in an international context, the ability to communicate with experts in other fields, interpersonal relationship skills, critical thinking, ethical commitment, the ability to review and criticise, and the ability to appreciate diversity and multiculturalism.

Specifically, the students developed and put into practice two interpersonal competences when using Facebook and QR codes: teamwork and the ability to work in an international context:

- Teamwork: this was one of the interpersonal competences that had the greatest impact - "the people who use it [...] can contribute ideas from their companies on the matter..." (Interview 1); "...we get closer to other people, and these in turn can discuss their experiences on the subject and therefore learn more..." (Interview 6); "...you have the opportunity to share and interact in real time [...] wherever you are..." (Interview 10); "...it unites everyone; it helps us all work better together..." (Interview 11).

- Ability to work in an international context: "trade with other countries via Facebook, since each country has the QR code application stamp for its products, and they're different and vary in many respects, helping 
us learn..." (Interview 1); "...they guide students on national and international technology" (Interview 7); "...you can expand different teaching strategies, achieving an educational and cultural exchange [...] and therefore broaden knowledge" (Interview 31); "...'d like the Spanish students to see my audiovisual material and to be able to see theirs too" (Interview 34).

\section{Development of systemic competences}

These competences refer to the ability to apply knowledge to practice, the ability to learn (to gain experience), autonomous learning, adapting to new situations, leadership, understanding other cultures and customs, initiative and entrepreneurship, motivation for quality, sensitivity to environmental issues, research skills, the ability to generate new ideas (creativity) and design and project management (Martínez López, 2008).

The participants in the study highlighted that systemic competences were the ones that they used the most in this experience, including research skills, initiative and entrepreneurship (creativity), motivation (achievement) and the ability to apply knowledge to practice:

- Research skills: "...it pushes you to do more research, especially the level at which it is developed in our country" (Interview 5); "it helped us [...] investigate and look into..." (Interview 3); "...doing research into what QR codes are, and how to use them [...] I started to use them more often [...] it's funny what the unknown creates..." (Interview 9); "...we were looking for our QR codes, looking up what they meant [...] designing our own QR codes..." (Interview 6); "... researched outside of my regular classes..." (Interview 13); "...it generates motivation to investigate [...] see what is important and innovative [...] their use in business and the world" (Interview 15); "... looked harder and explored more and more..." (Interview 23).

- Initiative and entrepreneurship (creativity): "...it gave us the opportunity to be creative" (Interview 3); "...design our own QR codes..." (Interview 6); "..I was interested in the subject and have researched outside of the regular classes..." (Interview 13); "...teaching and motivating strategy [...] helps you become more innovative..." (Interview 11); "... had several friends who [...] even helped me find QR codes" (Interview 11); "... found myself constantly looking for QR codes, to see what we are using in our country" (Interview 40).

- Motivation (achievement): "it's very motivating, something new and innovative, I really enjoyed it" (Interview $2)^{\prime \prime . . . I ~ f o u n d ~ i t ~ v e r y ~ m o t i v a t i n g ~[. . .] ~ i t ~ g e n e r a t e d ~ a ~ d e g r e e ~ o f ~ c o m m i t m e n t ~ t o ~ t h e ~ s u b j e c t, ~ n o t ~ j u s t ~ a t ~ t h e ~ t i m e, ~ b u t ~}$ to learn and interact..." (Interview 3); "it created incentives to understand the subject" (Interview 4): "...we spent several hours in the Metropolis Shopping Centre, in shop after shop [...] we were more excited about finding QR codes [...] we visited several places and establishments" (Interview 11).

- Ability to apply knowledge to practice:....during the search we could see the current market, in ourcase,Venezuela..." (Interview 1); "...the student can be updated and have closer contact with the markets [...] the people working in them [...] they can contribute ideas from their companies in relation to the matter..." (Interview 1); "... began to observe and be more aware of the presence of this technology in my environment [...] incorporating this idea into other subjects or courses that I was studying..." (Interview 10); "doing research projects on things like these codes and their application in the market, and how their application has revolutionised many aspects" (Interview 10).

To summarise, the following table presents the analysed dimensions, the extracted categories and the computed frequencies to which reference has been made (Table 2) 
Table 2. List of dimensions, categories, and frequencies.

\begin{tabular}{|l|l|c|}
\multicolumn{1}{|c|}{ Dimensions } & \multicolumn{1}{|c|}{ Categories } & Frequency \\
\hline \multirow{3}{*}{$\begin{array}{c}\text { 1. Interpersonal competences } \\
\text { (IPC) }\end{array}$} & 1.1.Teamwork (CIPTE) & 43 \\
\cline { 2 - 3 } & 1.2. Ability to work in an international context (CIPTI) & 36 \\
\hline \multirow{4}{*}{ 2. Systemic competences (STC) } & 2.1. Research skills (CSTHI) & 41 \\
\cline { 2 - 3 } & 2.2. Initiative and entrepreneurship (creativity) (CSTIEE) & 39 \\
\cline { 2 - 3 } & 2.3. Motivation (achievement) (CSTM) & 35 \\
\cline { 2 - 3 } & 2.4. Ability to apply knowledge to practice (CSTCP) & 40 \\
\hline \multirow{2}{*}{$\begin{array}{c}\text { 3. Instrumental competences } \\
\text { (ITC) }\end{array}$} & 3.1. Capacity for analysis and synthesis (CITAS) & 39 \\
\cline { 2 - 3 } & 3.2. Ability to organise and plan (CITOP) & 42 \\
\hline
\end{tabular}

\section{Conclusions and limitations}

In relation to the attitudes towards $Q R$ codes, it should be noted that, in some cases, the students were very open to them. In others, their non-use could be explained by their lack of knowledge of how they worked or how they were produced. But once trained in these competences, the students recognised that they made the work much easier, that they were very effective and useful to access other multimedia resources, and therefore, highly recommendable and beneficial to them.

With regard to Facebook, we must admit that this is not the first research project in which this social network has been analysed as a study tool in higher education. Other authors such as Konstantinou (2013) have recently used it with students from the Technological University of Cyprus. She defines it as motivating, able to capture the students' attention, a facilitator of information and online gaming, ideal to provide a query window open 24 hours, perfect for helping students to meet other students outside a formal setting, and competent to remove certain barriers between teachers and students, and this article agrees with her opinions. Indeed, they fully coincide with the different comments made by participants in this study. What has been truly innovative is seeing how the use of QR codes in higher education using Facebook as an instrument has served to enhance and develop general competences.

The study's participants said that Facebook is a close, reliable, easy-to-use tool, which has advantages over other networks and platforms, such as creating an environment where people from different places can meet and share educational experiences ("I find it beneficial to use social media to research, analyse and carry out evaluated projects", Interview 34). Furthermore, according to their contributions, we could see, through social networks that they were able to acquire and develop instrumental, interpersonal and systemic competences. In this sense, we are of the opinion that such environments should be designed and planned in order to improve the processes of teaching and learning at university.

These conclusions were also reached by Professor Piñol Bastidas (2012). She said that Facebook worked quite well on the Conservation of Cultural Heritage course at the University of Barcelona due to the proximity of communication and the strengthening of personal relationships with the students, among other things. 
At the time of writing this article, the outcome of this work was quite positive; students from the participating universities had expressed their satisfaction with using social networks (Facebook) as tools for acquiring competences and improving learning, as each student had made contributions from different perspectives, some from the field of education and others from the field of marketing or communication.

This study also coincides with Gómez and López (2010), who claimed that social networks were emerging as an alternative to peer communication and could be used as an educational tool, albeit with a highly informative but non- educational value at that time. Furthermore, as the main problem associated with social networks like Facebook is the privacy of the data being published on them, it cannot be overlooked (Gómez \& López, 2010; Reig, 2011).

The use of social networks should not be something isolated from classes, as Rubén Morelli (2011) said. He has suggested that Facebook should be used as a complement to the dynamics of the learning process and not a replacement.

Combining innovative QR codes and Facebook led to a very interesting and dynamic piece of work among university students from both countries, and it should be a reference point to take into account in future studies in teaching methods.

As for limitations to this study, we should note that the failure to increase the sample size of students in all groups and courses, or even in other departments, restricts the generalizability of the findings obtained here.

\section{References}

Allueva, A. (2013). Experiencia de uso de los códigos QR en docencia. EuLES Retrieved from http://eules.unizar.es/ archives/1865

Bombillar, F. M. (2010). Bolonia y Pisa: algo más que dos ciudades italianas. Una reflexión acerca de los nuevos retos a los que se enfrenta la educación universitaria en España. Zona Próxima, 1(12), 208-221. Retrieved from http:// www.redalyc.org/pdf/853/85316155014.pdf

Cabero, J., Alba, J. M., López-Arenas, J. M., \& Pérez, J. L. (1991). Posibilidades cognitivas y educativas de la informática. Proyecto presentado al Concurso Nacional de Proyectos de Investigación Educativa, resolución de 22 de diciembre de 1988, de la Secretaría de Estado de Universidades y Educación. BOE del 15 de febrero de 1989.

De Miguel, M. (2005). Cambio de paradigma metodológico en la educación superior. Exigencias que conlleva. Cuadernos de integración europea, 2, 16-27. Retrieved from http://cde.uv.es/documents/2005-02-16.pdf

Domènech, R. (2011). Códigos QR como propuesta de trabajo desde el área de música. Eufonía: Didáctica de Música, 52, 26-34.

Gálvez, D. (2012). MineQRale. Retrieved from http://www.divshare.com/flash/slide?myld=18186268-232

Gamboa Jiménez, J. L. (2012). Actividades con códigos QR en el aula [Web log post]. Retrieved from http:// cerrodelaslombardas.blogspot.com.es/2012/02/actividades-con-codigos-qr-en-el-aula.htm

Geyer, S. (2010). 7 ways higher education can use QR codes to connect with current and prospective students [Web log post]. Retrieved from http://blog.noellevitz.com/2010/11/24/7-ways-higher-education-qr-codes-connectcurrent-prospective-students/

Gómez, M. T., \& López, N. (2010). Uso de Facebook para actividades académicas colaborativas en educación media y 
universitaria. III Jornadas de Educación a Distancia. Las redes sociales y la gestión del conocimiento. Del 26 al 30 de abril de 2010. Retrieved from http:// www.salvador.edu.ar/vrid/publicaciones/USO_DE_FACEBOOK.pdf

Harvard University (2011). QR Codes in the Library: A Window to On-Line Research Services. Retrieved from http://osc. hul.harvard.edu/liblab/proj/qr-codes-library-window-line-research-services

Hernández Ortega, J. (2012). Animación a la lectura. Retrieved from http://es.scribd.com/doc/92114610/Animaciona-la-lectura

Ivala, E., \& Gachago, D. (2012). Social media for enhancing student engagement: the use of Facebook and blogs at a university of technology. South African Journal of Higher Education, 26(1), 152-167. Retrieved from http://www. academia.edu/4076740/Social_media_for_enhancing_student_engagement_The_use_of_Facebook_and_ blogs_at_a_University_of_Technology

Konstantinou, J. (2013). ¿Es posible aprender a través de Facebook? Práctica docente. XXII Jornadas de ASPE (Asociación de profesores de español e hispanistas en Grecia) [Web log post]. Retrieved from http://aspegr. blogspot.com.es/2013/04/es-posible-aprender-traves-de-facebook.html.

Llorente, M. C. (2008). Blended learning para el aprendizaje en nuevas tecnologías aplicadas a la educación: un estudio de caso (Unpublished doctoral dissertation). Seville: Universidad de Sevilla. Retrieved from http://fondosdigitales. us.es/tesis/tesis/656/blended-learning-para-el-aprendizaje-en-nuevas-tecnologias-aplicadas-a-la-educacionun-estudio-de-caso/

Manca, S., \& Ranierit, M. (2013). Is it a tool suitable for learning? A critical review of the literature on Facebook as a technology-enhanced learning environment. Journal of Computer Assisted Learning, 29(6), 487-504. doi http:// dx.doi.org/10.1111/jcal.12007

Marín, V., \& Romero, M. A. (2009). La formación docente universitaria a través de las TIC. Pixel-Bit, Revista de Medios y Educación, 35, 97-103. Retrieved from http://www.redalyc.org/articulo.oa?id=36812381008

Marquis, J. (2012). Your Quick-Guide To Using QR Codes In Education. Retrieved from http://www.teachthought.com/ technology/your-quick-guide-to-using-qr-codes-in-education/

Martínez López, J. (2008). La opinión de los profesores universitarios. In ICE de la Universidad de Zaragoza. Competencias genéricas y transversales de los titulados universitarios, 28-33. Retrieved from http://www.unizar.es/ice/images/ stories/publicacionesICE/Col.\%20Documentos\%2008.pdf

Morelli, R. D. (2011). Experiencia de uso de Facebook en la dinámica del proceso de aprendizaje. VII Congreso Nacional de profesores de expresión gráfica en ingeniería, arquitectura y carreras afines. "Re-visión de la expresión gráfica. Nuevos enfoques". Retrieved from http://www. fceia.unr.edu.ar/dibujo/Egrafia2011_MorelliRD.pdf

Moreno, I. (2011). Aplicaciones de la web en la enseñanza. Madrid: Catarata.

Osgood, C., Suci, G., \& Tannenbaum, P. (1976). La medida del significado. Madrid: Gredos.

Piñol Bastidas, R. (2012). Redes sociales y docencia: Facebook. Barcelona: Universidad de Barcelona. Retrieved from http://2012ubroser.blogspot.com.es/2012/01/facebook-en-relacio-al-blog-doscar.html

Proyecto Tuning (2007). Tuning Educational Structures in Europe. La contribución de las universidades al proceso de Bolonia. Socrates-Tempus. Retrieved from http://www.unizar.es/eees/tesie.htm

Reig, D. (2011). Facebook apuesta por las redes sociales en educación superior. Retrieved from http://www.dreig.eu/ caparazon/2011/12/10/facebook-grupos-de-universitarios/.

Román, P. (2012). Diseño, elaboración y puesta en práctica de un observatorio virtual de códigos QR. Revista d'innovació educativa, 9, 96-107. doi http://dx.doi.org/10.7203/attic.9.1947 
Román, P., Díaz, M. C., Puig, M., \& Martín, Á. (2012). Una nueva manera de enseñar a colaborar a través de las redes sociales. Prácticas Innovadoras en Docencia Universitaria. Universidad de Sevilla. Retrieved from http://fcce.us.es/ sites/default/files/docencia/Mesa4_comunicacion7.pdf

Ruiz, C. (1998). Instrumentos de investigación educativa. Barquisimeto: Cideg.

Stanford University (2012). QR codes pilot project in Jonsson Reading Room [Web log post]. Retrieved from https:// www.stanford.edu/group/ic/cgi-bin/drupal2/node/1508

Universidad de Oviedo (2012). La Universidad de Oviedo incorpora la realidad aumentada a su edificio histórico. Retrieved from http://www.uniovi.es/prensa/actualidad//asset_publisher/0001/content/la-universidad-deoviedo-incorpora-la-realidad-aumentada-a-su-edificio-historico

Universidad de Sevilla (2012). Códigos QR en el catálogo fama clásico y en mi cuenta. Retrieved from http://bib.us.es/ Soporte-news/news/bus_120619_codigos_qr-ides-idweb.html

Watson, E. (2013). Discovering the innate potential of $Q R$ codes in Education. Retrieved from http://www. educationandtech.com/2013/12/qr-codes-secrets-in-education.html

Zambrana, L., \& Manzano, V. (2004). ¿Hacia dónde camina la universidad? Reflexiones acerca del EEES. Revista Interuniversitaria de Formación del Profesorado, 18(3), 269-276. Retrieved from http://www.redalyc.org/articulo. oa?id=27418318

\section{About the authors}

Pedro Román Graván proman@us.es

Lecturer, Department of Teaching and Educational Organisation (Curriculum and Educational Organisation), Faculty of Education Sciences, University of Seville (US), Spain

He holds a PhD in Educational Studies and is a lecturer in the Department of Teaching and Educational Organisation (Curriculum and Educational Organisation) in the Faculty of Education Sciences at the University of Seville (US), Spain, where he teaches Educational Technology and New Technologies Applied to Education in Educational Studies and Primary Education. He is a member of Grupo Comunicar (professional association of Andalusian journalists and teachers) and Grupo de Investigación Didáctica (GID) Teaching Research Group: Technology and Qualitative Analysis of the TeachingLearning Process. He has taught various masters such as Training and Vocational Guidance for Employment (US) and New Technologies applied to Education (University Postgraduate Institute, University of Alicante, Autonomous University of Barcelona, University Carlos III of Madrid, Santillana Training). He has been a reviewer of several national and international journals such as Relatec (ISSN: 1695-288x), @tic. revista d'innovació educativa (ISSN: 1989-3477) and Hekademos (ISSN: 19893558), among others. He has written several articles on education, educational technology and new technologies, and has given numerous lectures and courses related to the application of new technologies in education. He has also supervised dissertations, research papers and final projects related to ICT. Currently, he is participating in competitive research projects funded by the Ministry of Education, Culture and Sports Red temática sobre Aprendizaje colaborativo en Entornos Virtuales (RACEV)' reference EDU2010-09535-E, and Diseño, producción y evaluación en un entorno de aprendizaje 2.0, para la capacitación del profesorado universitario en la utilización educativa de las tecnologías de la información y comunicación (DIPRO 2.0)² reference EDU2009-08893.

http://eduformacion.us.es/proman

1. Thematic Network on Collaborative Learning in Virtual Environments

2. Design, production and evaluation in a 2.0 Learning environment for training university teachers on the educational use of information technology and communication 


\section{Ángela Martin Gutiérrez}

amarting@us.es

Research Fellow, Department of Teaching and Educational Organisation, Faculty of Education Sciences, University of Seville (US), Spain

She holds a bachelor's degree in Educational Studies and a master's degree in Quality Management Assessment of Training Institutions, and is a lecturer in the Department of Teaching and Educational Organisation at the University of Seville (US), Spain, where she teaches on degrees in Educational Studies and Primary Education, both of which are offered by the Faculty of Education Sciences. She is currently carrying out her doctoral thesis on Contextualización de los Centros de Formación Profesional en su entorno: retos y oportunidades en la sociedad del conocimiento 3 in the Department of Teaching and Educational Organisation, US. She is a member of the Grupo de Investigación Didáctica (GID) Teaching Research Group: Technology and Qualitative Analysis of the Teaching-Learning Process. She is also a member of the Evaluation Committee for the journal INNOVAR, in the Faculty of Economic Sciences at the National University of Colombia, Bogota. She has been the executive secretary of the journal Fuentes (Faculty of Education Sciences, US) and an external evaluator of communications in Secondary Education at the // Congreso Internacional Multidisciplinar de Investigación Educativa ${ }^{4}$ (2013). She has also written articles on education and has taught workshops and courses related to the application of new technologies in education.

\section{C/ Pirotecnia s/n \\ 41013 Sevilla \\ Spain}

Original title Las redes sociales como herramientas para la adquisición de competencias en la universidad: los códigos QR a través de Facebook

The texts published in this journal are - unless indicated otherwise - covered by the Creative Commons Spain Attribution 3.0 licence. You may copy, distribute, transmit and adapt the work, provided you attribute it (authorship, journal name, publisher) in the manner specified by the author(s) or licensor(s). The full text of the licence can be consulted here: <http://creativecommons.org/licenses/by/3.0/es/deed.en>

3. Contextualising Vocational Training Centres in their environment: challenges and opportunities in the society of knowledge

4. II International Multidisciplinary Conference for Educational Research 